\title{
Bariatrik Cerrahi Geçiren Hastaların Roy'un Uyum Modeline Göre Değerlendirilmesi: İki Olgu Sunumu
} Assessment of Patients Undergoing Bariatric Surgery According to The Roy's Adaptation Model: Two Case Reports

\author{
(Olgu Sunumu)
}

\author{
Meryem Yılmaz*, Pınar Yılmaz
}

öz

\begin{abstract}
Obezite karmaşık, multifaktöriyel ve büyük ölçüde önlenebilir bir hastalıktır. Günümüzde dünyadaki tüm ülkelerde alarm düzeyine erişmiştir. Bu nedenle günümüzde obezite ile mücadelede birçok tedavi yöntemi geliştirilmiştir. Bunlardan birisi bariatrik cerrahidir. Bariatrik cerrahi sonrası yeme, yaşam tarzı ve beden imajında önemli değişimlerden dolayı bireyler ciddi uyum sorunu yaşayabilmektedir. Hemşirelikte yaygın olarak kullanılan Roy'un Uyum Modeli (RUM); içerdiği dört uyum alanında bireylerin uyum gereksinimlerini belirlemeye ve insanın uyum sistemi ve çevresinde meydana gelen değişimlere odaklanmaktadır. Bu olgu çalışması 2017 yılında bir üniversite hastanesinde bariatrik cerrahi geçiren iki olgu, RUM’a göre bir kez ameliyat öncesi, dört kez ameliyat sonrası görüşme yöntemi ile değerlendirildi. Bu çalışmada birinci olgunun, RUM’a göre uyum sağladığı, ikinci olgunun uyum sağlayamadığı, fizyolojik ve psikolojik komplikasyonlar yaşadığı belirlendi. Çalışmada, RUM hastaların sistematik değerlendirilmesini, izlenmesini kolaylaştırdı ve sorunların saptanmasını sağladı. Bu nedenle hemşirelerin bariatrik cerrahi sonrası bireylerin yaşayabileceği uyum problemlerini ameliyat öncesi dönemden itibaren RUM’a göre değerlendirmesi ve saptanan sorunların çözümü için gerekli girişimlerin planlaması ve uygulaması ile uyumu kolaylaştırabileceği sonucuna varıldı.
\end{abstract}

Anahtar Kelimeler: Bariatrik cerrahi, hemşirelik, obezite, Roy adaptasyon modeli

\begin{abstract}
Obesity is a complex, multifactorial, and largely preventable disease. Today, all countries in the world have reached the alarm level. For this reason, many treatment modalities have been developed in the fight against obesity today. One of them is a bariatric surgery. Individuals may experience serious adjustment problems due to significant changes in eating, lifestyle and body image after bariatric surgery. Roy's Adaptation Model (RAM), widely used in nursing, focuses on determining the adaptation needs of the individuals in the four areas of integration and the changes that occur in and around the human adaptation system. In this case study, two patients who underwent bariatric surgery in a university hospital in 2017 were evaluated preoperatively one time and postoperatively four times according to RAM. In this study, it was determined that the first case adapted according to RAM while the second case could not adapt and have physiological and psychological complications. In the study, RAM facilitated the systematic evaluation and monitoring of patients and made it possible to identify problems.
\end{abstract}

"Cumhuriyet Üniversitesi Sağlık Bilimleri Fakültesi Hemşirelik Bölümü Cerrahi Hastalıkları Hemşireliği Anabilim Dalı, Sivas, Türkiye, E-Posta: yilmazmm01@hotmail.com, Tel: 03462191650 -2508,ORCID: https://orcid.org/0000-0001-7686-3572

*"Cumhuriyet Üniversitesi Sağlık Bilimleri Fakültesi Hemşirelik Bölümü Cerrahi Hastalıkları Hemşireliği Anabilim Dalı, Sivas, Türkiye, E-Posta: pyilmaz@cumhuriyet.edu.tr,Tel: 034621910 10,ORCID: https://orcid.org/0000-0002-4696-8776

Geliş Tarihi: 11 Aralık 2017 Kabul Tarihi: 08 Kasım 2018

Atıf/Citation: Yılmaz M., Yılmaz P. Bariatrik Cerrahi Geçiren Hastaların Roy'un Uyum Modeline Göre Değerlendirilmesi: Iki Olgu Sunumu. Hacettepe Üniversitesi Hemşirelik Fakültesi Dergisi 2019; 6(1):65-73. DOI: 10.31125/hunhemsire.544146 
Thus, it was concluded that the nurses could evaluate the adaptation problems experienced by the individuals after the bariatric surgery according to the RAM from the preoperative period and could facilitate the adaptation by planning and applying the necessary interventions to solve the identified problems.

Key Words: Bariatric surgery, nursing, obesity, Roy's adaptation model

\section{Gíriş}

Obezite karmaşık, multifaktöriyel ve büyük ölçüde önlenebilir bir hastalıktır. Obezite tipik olarak boya göre fazla beden ağırlığı olarak tanımlanır, ancak, bu basit tanım, yalnızca beden büyüklüğü açısından değil, metabolik olarak da ortaya çıkabilen aşırı yağlanma ile ilişkili etiyolojik olarak karmaşık bir fenotiptir'. Obezite 1950'li yıllarda sorun olarak ortaya çıkmış ve 1980’li yıllarda, her iki cinsiyet için neredeyse ikiye katlanmıştır. Günümüzde ise, dünyadaki tüm ülkelerde alarm düzeyine erişmiştir. Bu artışın nedenleri; diyet ve aktivite örüntülerindeki değişiklikler, fazla yağ ve kalori içeren büyük porsiyon yiyecekler ve kentleşme nedeni ile sedanter yaşam stili gösterilmektedir ${ }^{1}$. Obezite salgınını besleyen yaşam tarzı ve çevresel faktörler, sinerjik bir şekilde hareket etmekte ve depresyon, diyabetes mellitus, kardiyovasküler hastalıklar ve belirli kanserlerin riskini

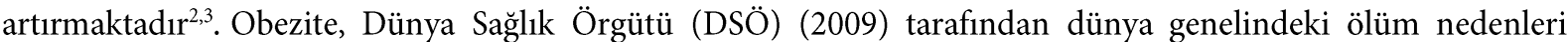
arasında beşinci sırada yer almaktadır. Ayrıca DSÖ, obezitenin dünyanın farklı bölgelerindeki ölümlerin\%1013 'ünden sorumlu olduğunun altını çizmektedir. Bu nedenle obezite ile mücadelede birçok tedavi yöntemi geliştirilmiştir. Bunlardan birisi bariatrik cerrahidir. Bilimsel kanıtlar, morbid obez hastalar için, obezitenin geniş kapsamlı yönetiminin integral bir parçası olarak, bariatrik cerrahinin en etkili tedavi yöntemi olduğunu ileri sürmektedir 5 .

Bariatrik cerrahi bireylerde kilo kaybının yanı sıra, beslenme değişiklikleri, emilim bozuklukları, hipotansiyon, hipoglisemi gibi geçici fizyolojik değişimlere de neden olan bir stresördür ${ }^{6}$ ve uyum gerektirir. Bireylerin bu değişimlere uyum sağlayabilmesi için kilit noktada yer alan hemşirenin bariatrik cerrahi geçirecek hastanın; ailevi ve kişilik özelliklerini içeren psikolojik ve davranışsal değerlendirmesini yapması ve beslenme özelliklerini sorgulaması ameliyat öncesi değerlendirmenin ayrılmaz bir parçası olmalıdır. Psikolojik değerlendirmenin amacı, yalnızca sorunları tanılamak için değil, potansiyel yaralanabilme, zorlanma ve güçlü yönlerin belirlenerek cerrahi tedavinin etkinliğini ve güvenliğini arttırmaktır. Ameliyat öncesi psikolojik değerlendirmede daima bireyin beklentisi, motivasyonu, diyet öyküsü, yaşam tarzı (örn; beslenme davranışı, fiziksel aktivitesi, alışkanlıkları, yaşam koşulları), sosyal destek gücünün değerlendirilmesi gerekmektedir. Ameliyat öncesi değerlendirme kilo yönetimi ve uzun süreli uyumu artırabilen (örn; kriz müdahalesi, psikolojik destek, psikoterapi, vb.) girişimlerin belirlenmesini mümkün kılabilir. Amaç, bariatrik cerrahiden önce ve sonra hastaların motivasyonu ile birlikte; beslenme, davranışsal ve psikososyal değişimlere uyum yeteneğini arttırmak, depresyon, anksiyete gibi psikolojik bozuklukları önleyebilmektir. Bunun yanı sıra hastaların cerrahi yöntemin tipine ve cerrahi sonrası geçen süreye bağlı olarak ameliyat sonrası aşamalı öğün geçişi ile ilişkili, öğünlerin sayısı ve miktarının arttırılmasının daha az kilo kaybına neden olacağı konusunda tekrarlı eğitilmesi gerekmektedir. Bariatrik işlemler sonrası tüm hastalar yaşam boyu düzenli olarak izlenmeli, hasta yaşam boyu izlem kurallarına uyum sorumluluğunu almalıdır ${ }^{7}$. Bu bağlamda hemşireliğin amacı, uyumun başarısını arttırmaktır. Hemşireler, uyumu artırmada bakımı sistematize etmek için bazı modelleri kullanabilirler. Bu modellerden birisi, Roy uyum modeli (RUM)'dir ${ }^{8}$ Bu modelin, onkoloji', cerrahi ${ }^{10}$, toplum sağlığ $1^{11}$, gibi çeşitli alanlarda uygulama için bir çatı/temel oluşturduğu bildirilmektedir. Roy tarafından tasarlanmış bu teorik modelde birey uyumlu/etkili ya da uyumsuz/etkisiz yanıtlar veren holistik adaptif bir sistem olarak algılanır. Bilindiği gibi insan sistemlerinin ana görevi, çevresel uyaranlar ile karşılaştığında bütünlüğünü sürdürmektir ve bireyin uyumu baş etme sürecine bağlıdır. RUM’a göre baş etme mekanizmalarının sonucunda dört uyum alanında etkili ya da etkisiz uyum davranışları ortaya çıkmaktadır ${ }^{8}$. 1960'larda gelişmeye başlayan RUM, hemşireliği bir bilim ve bu bilimden elde edilen bilginin hemşirelik uygulaması içine adaptasyonu olarak tanımlamaktadır ${ }^{12}$. Hemşirelik biliminde bakım, hemşirelik süreci ile gerçekleştirilir. RUM'da tanımlanan hemşirelik sürecinde altı adım vardır: davranışsal değerlendirme, uyaran değerlendirmesi, hemşirelik tanısı, hedef belirleme, girişim ve değerlendirme. İlk adım, bireyin belirli koşullara yönelik eylem ve yanıtlarını içeren davranışlarının değerlendirilmesidir. İkinci adım, yanıtı tetikleyen uyaranın (odak vs) belirlenmesidir. Üçüncü adım hemşirelik tanısıdır. Hemşirelik tanısı, hemşirenin hastanın uyum düzeyi hakkındaki kararını yansıtır ve bu, pozitif uyum veya uyum sorunlarının bir göstergesi olabilir. Hedef belirleme dördüncü adımdır ve hedefler birey tarafından gerçekleştirilecek nihai davranışlardır. Beşinci adım olan müdahale, hemşirelik bakımının seçimi olarak tanımlanmaktadır. Son olarak, 
altıncı adım, hemşirelik müdahalesinin insan sisteminin davranışına etkililiğinin değerlendirilmesini içeren bir değerlendirmedir.

Bariatrik cerrahi ciddi yaşam tarzı değişimi ve bu değişime uyum için uzun dönem gerektiren bir girişimdir. Bu nedenle bu çalışma iki bireyin, bariatrik cerrahi sonrasında 6 ay boyunca yaşam tarzındaki değişikliklerine uyumu, Roy teorik modelinin bileșenleri açısından değerlendirildi.

Çalışma 2017 yılında bir üniversite hastanesinin genel cerrahi ünitesinde yapıldı. Çalışmada yer alan her iki olgu da aynı gün ameliyat oldu. Çalışmada veri toplama işlemine başlamadan önce bireylere çalışmanın amacı açıklandı, sözel izinleri alındı. Her iki olguya ameliyat öncesinde, ameliyat sonrası değişen ve uymaları gereken kurallara yönelik araştırmacılar tarafından literatür doğrultusunda sözel eğitim yapıldı, eğitim her görüşmede bireyin gereksinimine ve yaşadığı soruna yönelik tekrarlandı. Taburculuk sonrası bireylere poliklinik kontrolüne gelmeden bir gün önce telefon edildi. Kontrole gelip gelmeyeceği öğrenildi. Görüşmeler birinci hafta, birinci ay, üçüncü ay ve altıncı ayda rutin kontrollere geldiğinde poliklinik odasında yapıldı. Birinci olgu 12 gün hastanede yattığı için ilk hafta görüşmesi hastanede, odasında yapıldı. Bu sözel eğitimde hastanın beslenme programı (8 öğün beslenme, sıvıdan katı beslenmeye geçiş, günlük sıvı tüketimi, besinlerdeki vitamin ve mineraller), günlük egzersiz programı (yürüyüş, yüzme, ağırlık çalışma vs.) ve ameliyat sonrası fizyolojik ve psikolojik olarak uyum süreci konuları ele alındı. Bunun yanı sıra her iki olguda gereksinim duyduğunda belirlenen görüşmenin dışında telefon ile araştırmacılardan danışmanlık aldı.

\section{Olgu 1}

24 yaşında, doktora eğitimine devam eden, bekar, $130 \mathrm{~kg}$ ve $1.54 \mathrm{~m}$ boyunda; beden kitle indeksi (BKİ) $54 \mathrm{~kg} / \mathrm{m}^{2}$ olan kadın hasta, ameliyat öncesi bedenini beğenmediği ve tip II diyabetes mellitus (DM) (AKŞ:113 mg/dl; Hbalc: \%5.7) ve atrial septal defekt (ASD) riski olduğu için bariatrik cerrahiye karar verdiğini ifade etti. Ameliyat öncesi hazırlıkta yapılan solunum fonksiyon testinde zorlandığı görüldü. Hastaya roux-en-y gastrik by-pass ameliyatı yapıldı. Hasta ameliyattan 4 saat sonra yoğun bakım ünitesinden kliniğe alındı ve mobilize edildi. Sarı renkli az miktarda kustuğu için hastaya proton pompa inhibitörü (PPI) başlandı. Ameliyat bölgesindeki hemovak drenden günlük 10-20 ml yeşil renkli, kokusuz sıvı geldiği için anostomoz kaçağı düşünüldü ve üç gün sürekli infüzyon şeklinde somatoson tedavisi uygulandı. Hastanın sol omuza vuran sırt ağrısı, CRP (257mg/L) ve WBC (27.ooo uL) değerlerinin yüksek olması dışında diğer anastomoz kaçağı bulguları gözlenmedi. Hastaya anostomoz kaçağı kontrolü yapıldıktan sonra rejim I (yalnızca su) ile oral başlandı, aynı zamanda $3000 \mathrm{ml} /$ gün total mayi devam etti. Hasta taburcu olmadan önce diyetisyen ile diyet planı oluşturuldu ve reçete edilen ilaçlar ile 13 gün sonra taburcu edildi. Görüşmelerde hastanın evde, eğitimde anlatılan yaşam tarzı değişikliklerine ve kurallara uygun davrandığını (ör: ilaçlarını düzenli kullanma, düzenli yürüyüş, yeme kuralları), günlük yaşam aktivitelerini (GYA) yerine getirmede zorlanmadığını, ailesinin kendisine destek olduğunu, sosyal ilişkileri ve yaşamdaki rol (evlat, kardeş, öğrenci) ve sorumluluklarını yerine getirmekte kısmen zorlandığını ifade etti. Hasta birinci ay $12 \mathrm{~kg}$, üçüncü ay $35 \mathrm{~kg}$ olmak üzere altıncı ayın sonunda toplam $50 \mathrm{~kg}$ verdi ve poliklinik kontrolünde demir eksikliği $(34 \mathrm{mcg} / \mathrm{dl})$ dışında diğer laboratuvar değerlerinde anormal değişiklik olmadığı belirlendi. Hasta kilo verme ile birlikte özgüveninin arttığını, aynadaki görüntüsünü beğendiğini, daha rahat soluk aldığını, mutlu olduğunu, istediği gibi giyinebildiğini, aralıklı kontrollerinde sağlıklı olduğunu ve yaşam kalitesinin iyileştiğini ifade etti.

\section{Olgu 2}

28 yaşında, lise mezunu, bekar, $110 \mathrm{~kg}$ ve $1.60 \mathrm{~m}$ boyunda; BKI $43 \mathrm{~kg} / \mathrm{m}^{2}$ olan kadın hasta ameliyat öncesi, fiziksel görüntüsünü beğenmediğini, bu durumun GYA yerine getirme ve sosyal ilişkilerinde kendisine engel oluşturduğunu ancak, ameliyat olma konusunda da kararsız olduğunu ifade etti. Hastaya sleeve gastrektomi ameliyatı yapıldı. Ameliyat sonrası yoğun bakımdan 19 saat sonra kliniğe alındı. Hasta yoğun bakımda iken dokuzuncu saat mobilize edildi. Yoğun bakımda iki kez şeffaf ve sekresyon içerikli kustuğu için hastaya PPI infüzyonu başlandı. Ameliyat sonrası üçüncü gün anostomoz kaçağı testi yapıldıktan sonra hemovak dreni çekildi ve oral başlandı (yalnızca su). Diyetisyen önerileri ve reçete edilen ilaçlar ile hasta bir hafta sonra kontrol önerilerek taburcu edildi. Bir hafta sonra kontrole gelen hasta, hiçbir şey yiyemediğini, yaşamdaki en büyük mutluluğunun yemek yemek olduğunu ve istediği kadar, istediği yiyecekleri yiyememesinin kendisini çok mutsuz ettiğini bu nedenle ameliyat olduğu için pişman olduğunu ifade etti. Ayrıca hastanın tedavi prosedürlerine (yemek yemesini engellediğini düşündüğü için önerilen ilaçları kullanmama) ve yeme tarzı değişikliklerine uymadığı belirlendi. Hastaya tedavi rejimine uymaz ise, oluşabilecek komplikasyonlar anlatıldı. 
Bir ay sonra ise, hasta bir daha kontrole gelmeyeceğini söyledi, bu ameliyat yüzünden çok pişman olduğunu tekrarladı. Üçüncü ayın sonunda hasta görüşmeyi reddetti. Ameliyattan beş ay sonra hastanın kendisi görüşmek istedi. Bu görüşmede, hasta toplam 28 kilo verdiği için fiziksel görüntüsünden dolayı toplumda daha çok beğenildiğini, özgüveninin arttığını ancak, kendisini kimsenin anlamadığını, yemek yiyebilmenin çok güzel olduğunu, istediği yiyecekleri yiyemediği için arkadaşları ile görüşmediğini ve evden dışarı çıkmadığını, sürekli yalnız kalmak istediği için aile ilişkilerinin zayıfladığını, uyku problemleri yaşadığını, midesini genişletmek için asitli-gazlı içecekler tükettiğini, fazla yemek yediğini ve her yemek sonrası kustuğunu, diyare olduğunu bu nedenle mutsuzluğunun devam ettiğini ifade etti. Ayrıca rol (evlat, ev hanımı, kadınlık) ve sorumluluklarını yerine getirmekte zorlandığını, "hiçbir iş yapmak istemediğiı"ni belirtti. Hasta altıncı ayda ailesinin baskısı ile kontrole geldiğinde yapılan tetkiklerde kreatinin:0.34 mg/dl; total protein:4.46 g/dl; kalsiyum:8.27 mg/dl; potasyum:3.2 mmol/L; Hb:10.5 g/dl değerlerinin düştüğü görüldü.

\section{Roy Uyum Modeli (RUM)}

RUM bireylerin, ailelerin ve grupların uyum gereksinimlerinin belirlenmesi için bir temel oluşturmaktadır. Modelin odaklandığı nokta, insanın uyum sisteminde ve çevresinde meydana gelen değişimlerdir. Modelde bireyler ve gruplar, davranışları çevresel uyaranlara bir tepki olan ve uyum sağlayabilen sistemler olarak kabul edilmektedir. Uyumun sağlanması, modelin temel konusudur ${ }^{8}$. Uyum, uyaranlara olumlu yanıt vermek olarak kabul edilmektedir. Çevresel uyaranlar direkt olarak baş etme süreci ile ilişkilidir ve her ikisi doğrudan ya da dolaylı olarak uyum yöntemi ile ilişkilidir. Roy, insanı etkileyen çevresel uyaranları üç bölümde sınıflandırmıştır. Bunlar; odak (fokal) uyaran, etkileyen/bağlamsal(contextual) uyaran ve kalıcı (rezidüel) uyaranlardır. Bu uyaranlar bireyleri ve grupları etkileyen sürekli değişen güçler olarak görülür. Odak uyaranlar, dıștan gelen ve bireyin ilk olarak karşılaştı̆̆ı, yanıt verdiği, uyum tepkisine doğrudan neden olan iç ve dış uyarılardır. Birey dikkatini bu yönde toplar ve enerji harcar. Etkileyen/bağlamsal uyaranlar, davranışın doğrudan nedeni olmayan; ancak davranışa etki eden uyarılardır. Bireyin iç ve dış dünyasından gelen, olayı etkileyen ve ölçülebilen, birey ya da grubun yanıtına doğrudan katkıda bulunan ve var olan durumu etkileyen diğer bütün uyaranlardır. Kalıcı uyaranlar ise durumu etkileyen bireylerin özellikleridir, belirsiz ve ölçülmesi zordur. Bunlar inançlar, davranışlar ve deneyimlerdir. Kalıcı bir uyaran belirlendiğinde, genellikle bir bağlamsal uyaran olur ancak, odak uyaran olduğu ortaya çıkabilir. Birey bu uyaranlara uyum sağlamayabilmek için baş etme mekanizmalarını kullanır8. Roy, çevresel uyaranlara verilen tepkilerin insanların davranışlarında ifade edilme biçimleri olan dört uyum alanı belirlemiş̧tir, bunlar; fizyolojik alan, kendini algılama/benlik kavramı alanı, rol fonksiyonu alanı ve karşlıklı dayanışma/bağllık alanıdır ${ }^{6,8}$.

\section{Şekil1. Roy Uyum Modeli ${ }^{13}$}

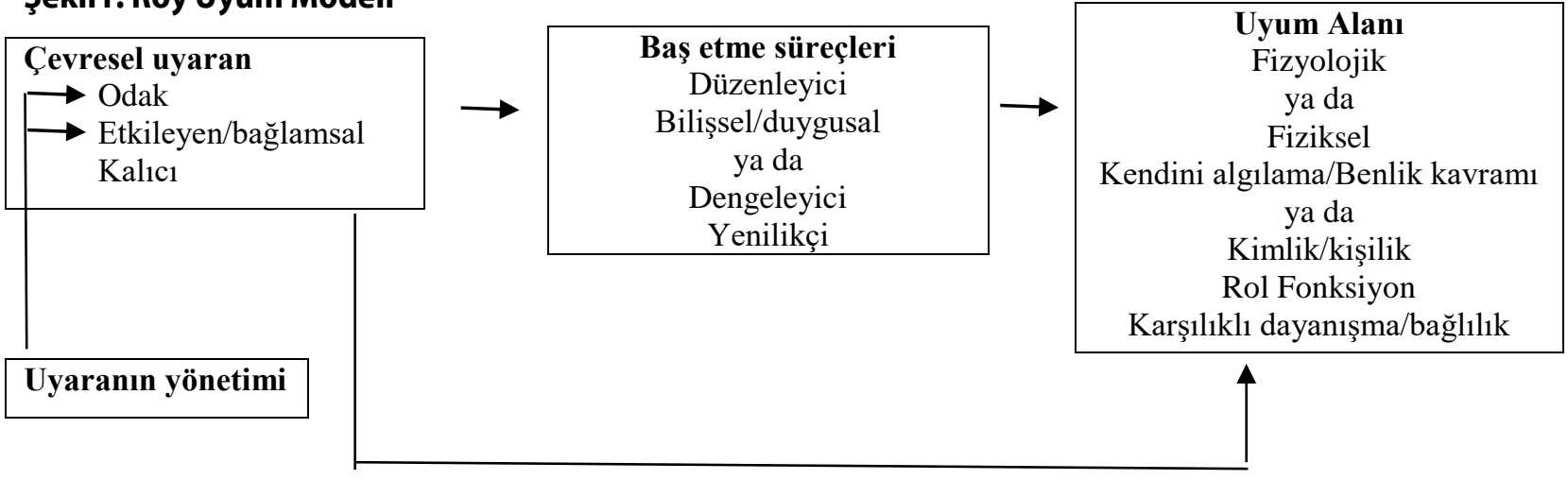

RUM’a göre uyumun fizyolojik alanı, yaşam bulguları ve klinik laboratuvar değerleri gibi biyolojik davranışları içerir ve çalışması gereken fonksiyon için gerekli temel kaynaklar üzerine odaklanır. Kendini algılama alanı, bireylerin bedenleri ve kişisel benlikleri hakkındaki duygularını içerir. Grup kimlik alanı, grubun üyelerinin nasıl göründüğü üzerine odaklanır. Rol fonksiyon uyum alanı, bireylerin ve grupların, toplumda uyguladıkları rollerle ilgili etkinliklerin performansına dikkat çeker. Karşılıklı uyum alanı, kişilerarası ilişkileri, sosyal desteğin verilmesi ve alınmasını vurgulamaktadır (Bkz. Şekil 1). RUM'da hemşirelik girişimlerinin çevresel uyaranların yönetimini içermesi gerekmektedir. Roy, bağlamsal uyaranların hesaba katılarak odak uyaranın yönetilmesine odaklanmasını önermektedir ${ }^{8}$. 
Bu çalışmada yer alan olguların RUM’a göre çevresel uyaranları Tablo1'de gösterildi. Olguların RUM’a göre uyum alanlarına ilişkin özellikleri de Tablo 2 'de verildi.

Tablo 1. Çalışmada Yer Alan Olguların RUM’a göre çevresel uyaranları

\begin{tabular}{|c|c|c|c|c|}
\hline & & ODAK UYARANLAR & ETKILEYEN UYARANLAR & KALICI UYARANLAR \\
\hline \multirow{2}{*}{ 공 } & 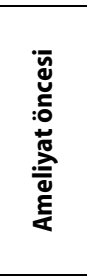 & -Obezite & $\begin{array}{l}\text {-Diabet riski, } \\
\text {-ASD riski, } \\
\text {-Hormonal bozukluklar } \\
\text {-Beden Memnuniyetsizliği -Genetik faktörler } \\
\text {-Obeziteyi destekleyen beslenme tarzı } \\
\text {-Düşük aktivite düzeyi } \\
\text {-Düşük benlik saygısı } \\
\text {-Solunum sıkıntısı }\end{array}$ & $\begin{array}{l}\text {-Bariatrik cerrahiye olan güçlü inancı } \\
\text { ve düşüncesi } \\
\text {-Bariatrik cerrahi ile ilişkili } \\
\text { medya/bilimsel yolla edindiği bilgi } \\
\text {-Yüksek eğitim düzeyi } \\
\text {-Güçlü farkındalık düzeyi } \\
\text {-Güçlü kararlılık }\end{array}$ \\
\hline & 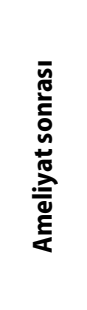 & $\begin{array}{l}\text {-Cerrahi } \\
\text {-Yaşam tarzında } \\
\text { değişim }\end{array}$ & $\begin{array}{l}\text {-Ağrı } \\
\text {-Lab bulguları } \\
\text { - Beslenme protokolüne uyum } \\
\text {-Düzenli aktivite yapma } \\
\text {-Güçlü aile desteği, } \\
\text {-Güçlü sosyal ilişkiler } \\
\text {-Yüksek benlik saygısı } \\
\text {-Kontrollere düzenli gelme } \\
\text {-Rol performansında düzelme }\end{array}$ & $\begin{array}{l}\text { - Bariatrik cerrahi ile ilişkili olumlu } \\
\text { inancı ve düşüncesi } \\
\text { - Yüksek eğitim düzeyi }\end{array}$ \\
\hline \multirow{2}{*}{ 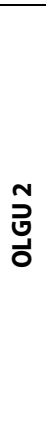 } & 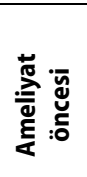 & -Obezite & $\begin{array}{l}\text {-Obeziteyi destekleyen yeme tarzının } \\
\text { yaşamın anlamı olması } \\
\text {-Düşük benlik saygısı } \\
\text {-Düşük aktivite düzeyi } \\
\text {-Beden Memnuniyetsizliği }\end{array}$ & $\begin{array}{l}\text {-Bariatrik cerrahi ile ilişkili } \\
\text { medya/bilimsel yolla edindiği bilgi } \\
\text { - Düşük eğitim düzeyi } \\
\text {-Zayıf farkındalık düzeyi } \\
\text {-Zayıf kararlılık }\end{array}$ \\
\hline & 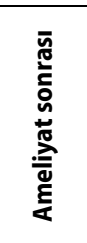 & $\begin{array}{l}\text {-Cerrahi } \\
\text {-Yaşam tarzında } \\
\text { değişim }\end{array}$ & $\begin{array}{l}\text {-Beslenme protokolüne uyumsuzluk } \\
\text {-Vitamin ve mineral eksikliği } \\
\text { - Sosyal ilişkilerde bozulma } \\
\text { - Zayıf aile desteği/aileyi kullanmama } \\
\text {-Kontrollere düzenli gelmeme } \\
\text {-Rol performansında bozulma }\end{array}$ & $\begin{array}{l}\text {-Bariatrik cerrahiye ilişkin olumsuz } \\
\text { inancı ve düşüncesi } \\
\text {-Spiritual distress } \\
\text {-Zayıf kararlılık } \\
\text {-Öğrenmeye kapalı olma } \\
\text {-Anlaşılmadığını düşünme } \\
\text {-Yakınma }\end{array}$ \\
\hline
\end{tabular}

\section{TARTIŞMA}

Bariatrik cerrahi, hasta için önemli yaşam tarzı değişikliğine neden olan bir odak uyarandır. Bu nedenle birey uyum sağlayabilmek ve bunu yaşamı boyunca sürdürmek için uzun süre dikkat ve enerjisini bu uyarana harcamaktadır.

Bu çalışmada her iki olgu da ameliyat öncesi beden imajından memnun değildi ve benlik saygıları düşüktü. Literatürde obez bireylerin benlik saygısının, normal kiloda olanlara göre daha düşük olduğu, BKİ arttıkça benlik saygısının azaldığı görülmüştür ${ }^{14}$. Sarısoy ve arkadaşları ${ }^{15}$ tarafından yapılan bir çalışmada, morbid obez bireylerin benlik saygısı puan ortalamalarının obez ve normal bireylerden daha düşük olduğu, obez bireyler ile sağlıklı kontrol grubu arasında benlik saygısı puanları arasında fark olmadığı belirlenmiștir. Ameliyat sonrası ise, ikinci olgunun cerrahi odak uyaranına yanıt olarak uyumsuzluk gösterdiği, benlik saygısı ve beden imajında istendik iyileşmenin sağlanamadığı, sosyal izolasyon yaşadığı görüldü. $\mathrm{Bu}$ sonuç, odak uyaranı etkileyen/bağlamsal uyaranlar ve kalıcı uyaranlardan kaynaklanmış olabileceği, bireyin bağlamsal uyaranlarını etkili yönetemediği ve ameliyat öncesi verilen eğitimin çoğunlukla fizyolojik alanın uyumuna yönelik olmasından kaynaklanmış olabileceği șeklinde yorumlanabilir. Ayrıca bilindiği gibi olumsuz beden imajı ve düşük benlik saygısı bireyin kişilerarası ilişkilerini de olumsuz yönde etkileyebilir, sosyal damgalanmaya ve sonuç olarak sosyal izolasyona yol açabilir. Bu bağlamda, RUM’a göre ikinci olgunun kendini algılama/benlik kavramı alanı ile ilişkili gereksinimi olduğu söylenebilir. Birinci olgu ise, önceki yapılan çalışmalara ${ }^{16-19}$ paralel olarak bariatrik cerrahi odak uyaranına yanıt olarak uyumlu davranışlar gösterdi. Kilo kaybı ile birlikte benlik saygısının yükseldiği, özgüvenin ve sosyal ilişkilerinin arttığı ve beden imajında önemli düzeyde iyileşme olduğu belirlendi. Bu sonuç 
doğrultusunda birinci olgunun fizyolojik alanındaki iyileşmenin benlik kavramı alanında da iyileşmesine katkı verdiği söylenebilir.

RUM’a göre, sağlık; uyaranlara yanıt olarak verilen uyumlu davranışların bir bütünüdür. Bu çalışmada birinci olgu, cerrahi sonrası yaşam tarzı değişiklikleri odak uyaranına uyumlu davranışlar gösterdiği, gerektiğinde sosyal desteklerini kullandığı ve rollerini yapabildiği için fizyolojik, rol fonksiyon ve karşılıklı bağlılık uyum alanının da iyileşmesi, kalıcı uyaranlarının da katkısı sonucu sağlığında ve yaşam kalitesinde artış olduğu söylenebilir. İkinci olgunun ise, tam tersine yaşam tarzı değişikliklerine uyumsuz davranışlar gösterdiği, gerektiğinde sosyal desteklerini kullanmadığı ve rollerini yapamadığı için fizyolojik, rol fonksiyon ve karşılıklı bağlllık uyum alanlarında iyileşme gerçekleşmediği, kalıcı uyaranlarının da katkısı ile sağlığı ve yaşam kalitesinin bozulduğu düşünülebilir. RUM'a göre çevresel uyaran direkt olarak baş etme süreci ile ilişkilidir. Bu nedenle, bireyin çevresel uyaranlara baş etme mekanizmalarını kullanarak verdiği yanıtların, yani davranışların değerlendirilmesi gerekir. Davranışlar dört uyum alanında (fizyolojik, benlik kavramı, rol fonksiyon ve karşılıklı bağlılık uyum alanı) yer alan gözlenebilen (nabız vs) ve gözlenemeyen davranışları (duyguları vs) içerir. İnsan davranışı ya da yanıtı; uyaran ve sistemin uyum düzeyidir. RUM'nin bir uyum alanındaki davranış diğer uyum alanlarındaki davranışları etkilemektedir. Bu nedenle hemşire hasta ile iletişime başladığı andan itibaren, davranışları değerlendirmeye başlamalı ve bakım sürecinin her aşamasında değerlendirme devam etmelidir. Bu çalışmada birinci olgunun RUM'un tüm uyum alanlarında uyumlu davranışlar sergilemiş olması, bir uyumlu davranışın başka uyumlu davranışa neden olduğu şeklinde yorumlanabilir. İkinci olgunun da tam tersine uyumsuz bir davranışının, diğer davranışlarını da olumsuz etkilediği ve görüşmelerde olumsuz durumu düzeltmek için verilen eğitiminde katkısının olmadığı söylenebilir.

Bariatrik cerrahi sonrası en ciddi komplikasyonlardan birisi anastomoz kaçağı olup, belirtileri giderek artan sırt ve sol omuz ağrısı, karın ağrısı, pelvik ağrı ve substernal baskıdır. Hıçkırık, huzursuzluk, dispne, açıklanamayan taşikardi, yüksek ateş, abdominal kontraksiyonlar ve hipotansiyon ilave bulgularıdır ${ }^{20}$. Bu çalışmada birinci olguda anostomoz kaçağından şüphelenilmiş ve yapılan tetkiklerde anostomoz kaçağı olmadığı belirlenmiştir. Birinci olgu, insizyon bölgesinde ilk 2 gün toplam 3 kez şiddetli ağrı yaşadı ve bunun dışında karın ağrısı yaşamadı. Yaşam bulguları normal sınırlarda seyretti. Anastomoz kaçağının teşhisi zordur. Bu çalışmada, her iki olguda da anostomoz kaçağının gelişmemesi bireylerin genç olması dolayısı ile fizyolojik uyum alanının güçü olmasının yara iyileşmesini hızlandırmış olmasından kaynaklanmış olabilir.

Mide ve ince barsak anatomisi ve normal sindirim fonksiyonları değiştiği için, en az altı ay boyunca bariatrik cerrahi sonrası hemen hemen tüm hastalarda "hızlı gastrik boşalma" ya da besinlerin ince barsağa hızlı geçişi sonucu vazomotor semptomlar ile karakterize dumping sendromu görülmektedir ${ }^{21}$. Proksimal ince bağırsakta mide içeriğinin ani varlığı, 30 dakikadan kısa sürede ekstraselüler sıvı ile birlikte bradikinin, serotonin ve enteroglukagon salınımı sonucu gelişen fizyolojik yanıt, erken belirtilere yol açar (uzanma ihtiyacı, çarpıntı, hipotansiyon, taşikardi, yorgunluk, baş dönmesi, terleme, baş ağrısı, kızarma, tokluk hissi, epigastrik ağrı ve dolgunluk, ishal, bulantı, kusma, kramplar, şişkinlik ve borborygmus). 90 dakika ile 3 saat içinde, yüksek insülin sekresyonu nedeni hipoglisemiye neden olan geç semptomlar (terleme, titreme, sıkıntı, bilinç kaybı ve açlık kaybı) ortaya çıkar ${ }^{21}$. Ancak bu çalışmada literatür verilerinin aksine her iki olguda da yukarıda belirtilen erken ya da geç dumping sendromu belirtileri gözlenmedi. Bu sonuç, her iki olgunun da genç olmasından dolayı fizyolojik uyum alanının değişime olumlu yanıt vermesinden kaynaklanmış olabileceği șeklinde yorumlanabilir. Bariatrik cerrahi sonrası oral başlama kriterleri diğer cerrahi girişimlerden sonra oral başlama kriterlerinden farklıdır. Bariatrik cerrahi sonrası, anastomotik sızıntıdan kaçınmak amacı ile üst gastrointestinal kontroller yapılıncaya kadar ağızdan hiçbir şey verilmez. Bu test genellikle ameliyattan sonraki gün yapılır. Test sonucunda sorun olmadığı belirlenirse, hastalara günde 6-10 kez 30 ml'lik sıvı verilerek oral başlanır ve protein içeren sıvı diyet ile devam edilir ${ }^{20}$. Barsak sesleri başladıktan sonra hastaya günlük altı küçük öğün şeklinde toplam 600-800 kalori verilmeli ve dehidratasyonu önlemek için hastanın sıvı alması desteklenmelidir ${ }^{22}$. Bu çalışmada birinci olgu yukarıda belirtilen beslenme protokolüne uyumlu davranmış ve altı ayda toplam $50 \mathrm{~kg}$ vermiş, fazla kilolarının \%61'inden; ikinci olgu ise, ameliyat sonrası beslenme protokolüne uymamış, mide hacmini büyütmeye çalışmış ve altı ayda $28 \mathrm{~kg}$ vererek fazla kilolarının \%25'inden kurtulmuştur. RUM'da insan uyaranlara doğuştan/düzenleyici (nöral, kimyasal, endokrin kanallarla) ya da kazanılmış/bilişsel/duyuşsal baş etme yolları ile (algısal ve bilgisel, öğrenme, karar verme ve duygusal) uyum sağlamaktadır. Uyaranlar karşısında düzenleyici ve bilişsel baş etme mekanizmaları devreye girmekte ve bu süreçlerin yeterliliği verilen yanıtları belirlemektedir. $\mathrm{Bu}$ süreçler uyuma katkı sağlar ise, etkili yanıt ya da uyumlu davranış, sağlamaz ise etkisiz yanıt ya da uyumsuz davranış oluşmaktadır ${ }^{23}$. Bu bilgiye göre ikinci olgunun düzenleyici ve bilişsel sistemlerinde yetersizlik olduğu 
için etkin baş etme mekanizmalarını kullanmadığı, bu nedenle uyumsuz davranışlar gösterdiği, bunun kalıcı uyaranlarından kaynaklandığı düşünülebilir. Bu çalışmada, ikinci olguda görüldüğü gibi uyumsuz davranışların oluşmaması için, bariatrik cerrahi sonrası RUM'un çevresel uyaranlarının yönetimini içeren (sürekli diyet değişiklikleri, yaşam stili modifikasyonu ve düzenli egzersiz vs) ve bağlamsal uyaranların hesaba katıldığı odak uyaranın yönetilmesine odaklanan multidisipliner bir yaklaşım önerilmektedir².

\section{SONUÇ ve ÖNERILER}

$\mathrm{Bu}$ olgu çalışmasından elde edilen sonuca göre; bariatrik cerrahi geçirecek olan bireylerin yaşayabilecekleri uyum sorunlara yönelik hemşirelik girişimlerinin Roy tarafından önerildiği gibi çevresel uyaranların yönetimini içermesi ve bağlamsal uyaranların hesaba katılarak odak uyaranın yönetilmesine odaklanması gerekmektedir. Çalışmada, RUM'un cerrahi girişim gibi uyum sağlanması gereken yaşam değişimlerinde uyum sorunlarının belirlenmesi ve uyumunu kolaylaştırabilecek gerekli girişimlerin planlanması için uygun bir araç olarak kullanılabileceği ve bu araştırmanın sonuçlarının, bariatrik cerrahi geçirecek hastaların uyum sürecine dayanan hemşirelik uygulamalarının geliştirilmesine katkı sağlayabileceği sonucuna varıldı.

\section{KAYNAKLAR}

1. Hruby A, Hu FH, The epidemiology of obesity: A big picture. Pharmacoeconomics 2015; 33(7): 673-689.

2. McGraw CA, Wool DB. Bariatric surgery: three surgical techniques, patient care, risks, and outcomes.AORN J 2015;102(2):141-52.

3. Kalan I, Yeşil Y. Obezite ile ilişkili kronik hastalıklar. Diyabet ve obezite 2010 (mised);24-25:78-81.

4. WHO Global Health Risks. Mortality and burden of disease attributable to selected major risks, 2009. http://www.who.int/healthinfo/global_burden_disease/GlobalHealthRisks_report_full.pdf (Erişim 02.08. 2018)

5. Cummings DE, Cohen RV.Beyond BMI: the need for new guidelines governing the use of bariatric and metabolic surgery.Lancet Diabetes Endocrinol 2014;2(2):175-81.

6. Tessier DJ, Eagon JC. Surgical management of morbid obesity. Curr Probl Surg 2008;45(2):68-137.

7. Fried M, Yumuk V, Oppert J-M, Scopinaro N, Torres AJ, Weiner R, et all. Interdisciplinary European Guidelines on metabolic and bariatric surgery. Obes Facts 2013;6:449-468.

8. Roy C. The Roy Adaptation Model. New Jersey Upper Saddle River. Pearson Prentice Hall Health 2009; 35-50.

9. Piazza D, Foote A, Holcombe J, Harris MG, Wright P. The use of Roy's adaptation model applied to a patient with breast cancer. European Journal of Cancer Care1992; 1:17-22.

10. Dunn HC, Dunn DG. The Roy adaptation model and its application to clinical nursing practice. Journal of Ophthalmic Nursing \& Technology 1997;16:74-78.

11. Dixon EL. Community health nursing practice and the Roy adaptation model. Public Health Nursing 1999;16: 290-300.

12. Ursavaş FE, Karayurt Ö, İşeri Ö. Meme kanseri nedeniyle meme koruyucu cerrahi yapılan bir hastaya Roy uyum modeline temellendirilmiş hemşirelik yaklaşımı. J Breast Health 2014;10:134-140.

13. Fawcet J. Using the Roy Adaptation Model to Guide Research and/or Practice: Construction of Conceptual-Theoretical-Empirical Systems of Knowledge. Aquichán 2009; 9(3):297-306.

14. Sarwer DB, Crerand CE. Body image and cosmetic medical treatments. Body image 2004; 1(1): 99-111.

15. Sarısoy G, Atmaca A, Ecemiş G, Gümüș K, Pazvantoğlu O. Obezite hastalarında dürtüsellik ve dürtüselliğin beden algısı ve benlik saygısı ile ilişkisi. Anadolu Psikiyatri Derg 2013; 14: 53-61.

16. Tam AA, Çakır B. Birinci basamakta obeziteye yaklaşım. Ankara Medical Journal 2012; 12(1):37-41.

17. Westman EC, Mcmahon RL, Grant JP. Binge eating, quality of life and physical activity improve after roux-en-y gastric bypass for morbid obesity. Obesity Surgery 2004; 14(3): 341. 
18. Sarwer DB, Spitzer JC, Wadden TA, James E. Mitchell MD, Kathryn Lancaster BA, et all. Changes in sexual functioning and sex hormone levels in women following bariatric surgery. JAMA surgery 2014; 149(1): 26-33.

19. Sarwer DB, Wadden TA, Moore RH, Eisenberg MH, Raper SE, Williams NN. Changes in quality of life and body image after gastric bypass surgery. Surgery For Obesity and Related Diseases 2010; 6(6):608-614.

20. Barth MM, Jenson CE. Post operative nursing care of gastric bypass patients. AmericanJournal of Critical Care 2006; 15(4):378-387.

21. Chaves YS, Destefanı AC. Pathophysiology, diagnosis and treatment of dumping syndrome and its relation to bariatric surgery. $A B C D$ Arq Bras Cir Dig 2016;29(Supl.1):116-119.

22. Gallagher S. Taking the weight off with bariatric surgery. Nursing March 2004; 34(3):58-64.

23. Çatal E. Dicle A. Teori-araştırma-bileşeni: Roy'un uyum modeli örneği. Dokuz Eylül Üniversitesi Hemşirelik Fakültesi Dergisi 2014; $1(7): 33-45$. 
Tablo 2. Çalışmada Yer Alan Olguların Roy'un Adaptasyon Modeline Göre Uyum Alanları ${ }^{8,12}$

\begin{tabular}{|c|c|c|}
\hline UYUM ALANLARI & TEMEL BİLGi & OLGULAR \\
\hline $\begin{array}{l}\text { Fizyolojik Alan } \\
\text { (Beslenme değişikliği, yaşam } \\
\text { tarzında değişim, yaşam } \\
\text { bulguları) }\end{array}$ & $\begin{array}{l}\text { Çevreden kaynaklanan uyaranlara bedensel olarak verilen } \\
\text { cevaplarla ilişkilidir. Oksijenlenme, beslenme, eliminasyon, } \\
\text { aktivite ve dinlenme, korunma, duyusal fonksiyonlar, sIVI- } \\
\text { elektrolit, nörolojik ve endokrin fonksiyonları içerir. }\end{array}$ & $\begin{array}{l}\text { OLGU } 1 \\
\text { Uyumlu davranış: } \\
\text { Cerrahi işlem sonrası beslenme değişikliklerine uyum göstermesi, düzenli } \\
\text { egzersiz, değişen günlük yaşam aktivitelerine uyum sağlaması, infeksiyona } \\
\text { karşı korunma, ağıı ile baş etme, laboratuvar ve yaşam bulgularının normal } \\
\text { olması. } \\
\text { OLGU } 2 \\
\text { Uyumsuz davranış: } \\
\text { Cerrahi işlem sonrası beslenme değişikliklerine uyum göstermemesi, } \\
\text { kusma, günlük yaşam aktivitelerini yapmada zorluk, diyare, elektrolit } \\
\text { dengesizlikleri, uyku bozuklukları, yaşam bulgularının normal, laboratuvar } \\
\text { bulgularının normal değerlerden düşük olması. }\end{array}$ \\
\hline $\begin{array}{c}\text { Kendini algılama/Benlik Kavramı } \\
\text { Alanı } \\
\text { (Şekil ve kilo fazlalığı) }\end{array}$ & $\begin{array}{l}\text { Kişinin kendisi hakkındaki inanç ve duygularının birleşimidir. } \\
\text { Özellikle kişinin fizyolojik ve akılsal görünümü üzerine } \\
\text { odaklanır. Fiziksel ben ve kişisel ben olmak üzere iki temel } \\
\text { bileşeni vardır. Fiziksel ben; beden imajı, görünüm ve } \\
\text { duygulanımı içerir. Kişisel ben ise; ahlaki ve spiritual değerler, } \\
\text { idealler, davranışlar ve kişisel standartların uyumunu içerir. }\end{array}$ & $\begin{array}{l}\text { OLGU } 1 \\
\text { Uyumlu davranış: } \\
\text { Kendisini psikolojik olarak iyi hissetmesi, beden imajının iyileşmesi, } \\
\text { özgüvenin artması, normal yaşamına devam etmesi, spiritual iyilik hali. } \\
\text { OLGU } 2 \\
\text { Uyumsuz davranış: } \\
\text { Duygu-durum bozuklukları, cerrahi işlem sonrası pişman olması, stresle baş } \\
\text { etmede güçlük, mutsuzluk, anksiyete, spiritual distress. }\end{array}$ \\
\hline $\begin{array}{c}\text { Rol Fonksiyon } \\
\text { Alanı } \\
\text { (Otonomi; kontrol duygusu) }\end{array}$ & $\begin{array}{l}\text { Rol kişinin toplumdaki pozisyonundan kaynaklanan ve bu } \\
\text { pozisyonu devam ettirmek için beklenen davranışları } \\
\text { göstermesidir. Kişinin üstlendiği üç çeşit rol vardır. Birincil rol, } \\
\text { kişinin yaşamındaki davranışların temelidir. İkincil rol, birincil } \\
\text { rol ve gelişimsel durum ile ilgili görevlerin bileşimidir. Üçüncül } \\
\text { rol, ikincil rollerle ilişkili rollerdir, geçicidir ve zevkler } \\
\text { doğrultusunda gelişir. }\end{array}$ & $\begin{array}{l}\text { OLGU } 1 \\
\text { Uyumlu davranış: } \\
\text { Cerrahi odak uyaranına uyumlu yanıt vermesi, evlat, kardeş, öğrenci gibi } \\
\text { rollerini sürdürmesi ve geliştirmesi. } \\
\text { OLGU } 2 \\
\text { Uyumsuz davranış: } \\
\text { Cerrahi odak uyaranına uyumsuz yanıt vermesi, evlat, ev hanımı, arkadaş } \\
\text { gibi rollerini devam ettirmede güçlük yaşaması, kadınlık rolünü içeren ev } \\
\text { işlerini yapamama. }\end{array}$ \\
\hline $\begin{array}{c}\text { Karşılıklı dayanışma/Bağlılık } \\
\text { Alanı } \\
\text { (Sosyal destek) }\end{array}$ & $\begin{array}{l}\text { Bireyin kişilerle ve destek sistemleri ile ilişkilerini kapsar. Bu } \\
\text { alanın odaklandığı iki spesifik ilişki vardır. Birincisi; bireyin } \\
\text { yaşamındaki en yakın kişi, en önemsediği insandır. Aralarında } \\
\text { sevgi, ilgi gösterme ve değer verme gibi kavramlar ön } \\
\text { plandadır. İincisi ise destek sistemlerdir. Bu kişilere karşı da } \\
\text { sevgi, ilgi ve değer verme durumları söz konusudur. Fakat } \\
\text { ilişkinin anlamı ve derinliği farklıdır. Yakın çevredekiler, } \\
\text { arkadaşlar, evcil hayvanlar bu gruba girer. }\end{array}$ & $\begin{array}{l}\text { OLGU } 1 \\
\text { Uyumlu davranış: } \\
\text { Uyarana/uyaranlara olumlu yanıt sonucu, sosyal ilişsilerin artması, } \\
\text { çevresindekilerden olumlu geribildirim alması, düzenli olarak hastane } \\
\text { kontrollerine gelerek sağlık çalışanlarından destek alması } \\
\text { OLGU } 2 \\
\text { Uyumsuz davranış: } \\
\text { Uyarana/uyaranlara olumsuz/yetersiz yanıt sonucu, sosyal izolasyon, ailesi } \\
\text { ile iletişiminin bozulması, anlaşılmadığını hissetmesi, ameliyat sonrası } \\
\text { düzenli kontrollere gelmeme ve sağlık çalışanlarının destek ve önerilerine } \\
\text { kapalı olması. }\end{array}$ \\
\hline
\end{tabular}

